\title{
FAKTOR-FAKTOR YANG BERHUBUNGAN DENGAN KELUHAN MUSCULOSKELETAL DISORDERS PEKERJA PENGANGKUT BARANG DI PASAR PANORAMA KOTA BENGKULU
}

\author{
Ullya Rahmawati \\ Poltekkes Kemenkes Yogyakarta \\ Jl Tatabumi No.3 Banyuraden Gamping Sleman DI Yogyakarta 405015 \\ E-mail: ullya88.rahmawati@gmail.com
}

\begin{abstract}
Factors Related to Musculoskeletal Disorders on Workers Porters In Panorama Market Of Bengkulu City. Workers porters are one part of the community that needs attention, because the work processes they carry out carry a lot of risks to their health status, one of which is complaints of musculoskeletal disorders (MSDs). Based on the results of a preliminary survey of 5 Bengkulu City Panorama Market workers porters, it was found that $100 \%$ had MSDs complaints. The purpose of this study was to determine the factors related to complaints of musculoskeletal disorders (MSDs) on workers porters at the Panorama Market in Bengkulu City. This study was an observational analytic study using a cross sectional study design. The population of the study was 124 freight carriers. The samples of this study were 124 workers with a total sampling technique. Chi square statistical test results found there is a relationship between work position and complaints MSDs $(p=0,000)$, there is a relationship of workload with complaints MSDs $(p=0.026)$, there is a relationship of age with complaints MSDs ( $p=0.006)$, there is a relationship between working period and complaints MSDs ( $p=$ $0.001)$ and there is a relationship between BMI and MSDs complaints ( $p=0.044)$. Suggestions that can be given for further research can add variables measuring environmental factors.
\end{abstract}

Keywords: Factors of Musculoskeletal Disorders; Musculoskeletal Disorders; Workers Porters.

\begin{abstract}
Abstrak: Faktor-Faktor yang Berhubungan dengan Keluhan Muskuloskeletal Disorders Pekerja Pengangkut Barang di Pasar Panorama Kota Bengkulu. Buruh angkut merupakan salah satu bagian dari masyarakat yang perlu mendapat perhatian, karena proses kerja yang mereka lakukan banyak mengandung resiko terhadap status kesehatan, salah satunya keluhan Muskuloskeletal disorders (MSDs). Berdasarkan hasil survey pendahuluan terhadap 5 buruh angkut Pasar Panorama Kota Bengkulu didapatkan 100 \% mengalami keluhan MSDs. Tujuan Penelitian untuk mengetahui Faktor-Faktor yang Berhubungan dengan Keluhan Musculoskeletal disorders (MSDs) pada Pekerja Pengangkut Barang di Pasar Panorama Kota Bengkulu. Penelitian ini bersifat analitik observasional dengan menggunakan rancangan penelitian cross sectional study. Populasi penelitian ini sebanyak 124 pekerja pengangkut barang. Sampel penelitian ini sebanyak 124 pekerja pengangkut barang dengan teknik pengambilan sampel total sampling. Hasil uji statistik chi square didapatkan ada hubungan sikap kerja dengan keluhan MSDs $(p=0,000)$, ada hubungan beban kerja dengan keluhan MSDs $(p=0,026)$, ada hubungan umur dengan keluhan MSDs ( $p=0,006)$, ada hubungan masa kerja dengan keluhan MSDs $(p=0,001)$ dan ada hubungan IMT dengan keluhan MSDs $(p=0,044)$. Saran yang dapat diberikan untuk penelitian selanjutnya dapat menambahkan variabel pengukuran faktor lingkungan.
\end{abstract}

Kata Kunci: Faktor Muskuloskeletal Disorders; Muskuloskeletal Disorders; Pekerja Pengangkut Barang. 


\section{PENDAHULUAN}

Buruh angkut merupakan salah satu bagian dari masyarakat yang perlu mendapat perhatian, karena proses kerja yang mereka lakukan banyak mengandung resiko terhadap status kesehatan, salah satunya keluhan Muskuloskeletal disorders (MSDs) dengan gejala sakit pada punggung dan pinggang, ketegagan pada leher, sakit pergelangan tangan, lengan dan kaki, dan banyak keluhan lainnya. Berdasarkan hasil survey pendahuluan terhadap 5 buruh angkut Pasar Panorama Kota Bengkulu didapatkan $100 \%$ mengalami keluhan MSDs. Rumusan penelitian adalah "FaktorFaktor Apakah yang Berhubungan dengan Keluhan Musculaskelatal Dirsorders (MSDs) pada Pekerja Pengangkut Barang di Pasar Panorama Kota Bengkulu". Tujuan Penelitian untuk mengetahui Faktor-Faktor yang Berhubungan dengan Keluhan Musculoskeletal disorders (MSDs) pada Pekerja Pengangkut Barang di Pasar Panorama Kota Bengkulu.

\section{BAHAN DAN CARA PENELITIAN}

Penelitian ini bersifat analitik observasional dengan rancangan penelitian cross sectional study. Sampel penelitian 124 pekerja dengan teknik pengambilan sampel total sampling. Teknik pengumpulan data dilakukan dengan cara observasi dan pengukuran untuk melihat sikap kerja, pengukuran berat dan tinggi badan untuk mengatahui Indeks Massa Tubuh. Untuk mengetahui beban kerja, umur, dan masa kerja dilakukan wawancara menggunakan lembar kuesioner. Instrumen pengumpulan data dengan Lembar penilaian Repaid Entire Body Assessment (REBA), Kuesioner Nordic Body Map (NBM), Kamera, Busur, Timbangan, Pengukur tinggi badan dan alat tulis. Analisis data dengan analisis univariat untuk mendeskripsikan sikap kerja, beban kerja, umur, masa kerja, Indeks Massa Tubuh (IMT), keluhan MSDs dalam bentuk tabel distribusi frekuensi dan analisis bivariat dengan melakukan uji chi square dilanjutkan dengan analisis multivariate logistic regression.

\section{HASIL PENELITIAN DAN PEMBAHASAN}

Analisis data penelitian ini dengan univariat dan multivariate dengan hasil penelitian sebagai berikut:

\section{Analisis Univariat}

Distribusi frekuensi faktor-faktor yang berhubungan dengan MSDs pekerja pengangkut barang dapat dilihat pada tabel berikut:

Tabel 1 Distribusi Frekuensi Faktor-Faktor yang Berhubungan dengan MSDs pada Pekerja Pengangkut Barang Di Pasar Panorama Kota Bengkulu

\begin{tabular}{|c|c|c|c|}
\hline No. & Faktor & Frekuensi & Persentase (\%) \\
\hline \multirow[t]{3}{*}{1.} & Sikap Kerja & & \\
\hline & Ergonomis & 23 & $18,5 \%$ \\
\hline & Tidak Ergonomis & 101 & $81,5 \%$ \\
\hline \multirow[t]{3}{*}{2.} & Beban Kerja & & \\
\hline & Tidak Berisiko (< $40 \mathrm{Kg}$ ) & 22 & $17,7 \%$ \\
\hline & Berisiko ( $\geq 40 \mathrm{Kg}$ ) & 102 & $82,3 \%$ \\
\hline \multirow[t]{3}{*}{3.} & Umur & & \\
\hline & Tidak Berisiko $(<35$ th $)$ & 23 & $18,5 \%$ \\
\hline & Berisiko ( $\geq 35$ th) & 101 & $81,5 \%$ \\
\hline \multirow[t]{3}{*}{4.} & Masa Kerja & & \\
\hline & Tidak Berisiko $(<5$ th $))$ & 19 & $15,3 \%$ \\
\hline & Berisiko ( $\geq 5$ tahun) & 105 & $84,7 \%$ \\
\hline \multirow[t]{3}{*}{5.} & Indeks Massa Tubuh & & \\
\hline & Tidak Berisiko (normal) & 42 & $33,9 \%$ \\
\hline & Berisiko (gemuk/kurus) & 82 & $66,1 \%$ \\
\hline \multirow[t]{3}{*}{6.} & Keluhan MSDs & & \\
\hline & Tidak Ada Keluhan $(\leq 28)$ & 22 & $17,7 \%$ \\
\hline & Ada Keluhan $(>28)$ & 102 & $82,3 \%$ \\
\hline
\end{tabular}


Pada tabel 1 diketahui bahwa dari 124 pekerja pengangkut barang di Pasar Panorama Kota Bengkulu sebagian besar sikap kerja pada pekerja tidak ergonomis yaitu 101 pekerja (81,5\% ), sebagian besar beban kerja pekerja berisiko yaitu sebanyak 102 pekerja $(82,3 \%)$, sebagian besar umur pekerja berisiko $(\geq 35$ tahun $)$ sebanyak 101 pekerja (81,5 \%), sebagian besar lama kerja $\geq 5$ tahun sebanyak 105 pekerja (84,7 \%), lebih dari sebagian IMT pekerja berisiko sebanyak 82 pekerja $(66,1 \%)$ dan sebagian besar pekerja mengalami keluhan musculoskeletal disorders sebanyak 102 pekerja (82,3\%).

\section{Analisis Bivariat}

Distribusi frekuensi faktor-faktor yang berhubungan dengan MSDs pekerja pengangkut barang dapat dilihat pada tabel berikut:

Tabel 2 Distribusi Frekuensi Faktor-Faktor yang Berhubungan dengan MSDs pada Pekerja Pengangkut Barang Di Pasar Panorama Kota Bengkulu

\begin{tabular}{|c|c|c|c|c|c|c|c|c|}
\hline \multirow[t]{3}{*}{ Faktor-Faktor } & \multicolumn{4}{|c|}{$\begin{array}{c}\text { Keluhan Musculoskeletal } \\
\text { Disorders }\end{array}$} & \multirow{2}{*}{\multicolumn{2}{|c|}{ Total }} & \multirow{3}{*}{$\begin{array}{l}\text { Hasil Uji } \\
\text { Statistik }\end{array}$} & \multirow{3}{*}{$\begin{array}{c}\text { OR } \\
95 \%\end{array}$} \\
\hline & \multicolumn{2}{|c|}{$\begin{array}{l}\text { Tidak ada } \\
\text { keluhan }\end{array}$} & \multicolumn{2}{|c|}{ Ada Keluhan } & & & & \\
\hline & $\mathbf{n}$ & $\%$ & $\mathbf{N}$ & $\%$ & $\mathbf{N}$ & $\%$ & & \\
\hline \multicolumn{9}{|l|}{ Sikap Kerja } \\
\hline Ergonomis & 17 & 13,7 & 6 & 4,8 & 23 & 18,5 & $p=0,000$ & 54.400 \\
\hline Tidak Ergonomis & 5 & 4,1 & 96 & 77,4 & 101 & 81,5 & & (14.914- 198.422) \\
\hline \multicolumn{9}{|l|}{ Beban Kerja } \\
\hline $\begin{array}{l}\text { Tidak Berisiko } \\
(<40 \mathrm{Kg})\end{array}$ & 8 & 6,4 & 14 & 11,3 & 22 & 17,7 & \multirow[t]{2}{*}{$p=0,026$} & \multirow{2}{*}{$\begin{array}{c}3.592 \\
(1.275-10.118)\end{array}$} \\
\hline $\begin{array}{l}\text { Berisiko } \\
(\geq 40 \mathrm{Kg})\end{array}$ & 14 & 11,3 & 88 & 71 & 102 & 82,3 & & \\
\hline \multicolumn{9}{|l|}{ Umur } \\
\hline $\begin{array}{l}\text { Tidak Berisiko } \\
(<35 \text { th })\end{array}$ & 9 & 7,2 & 14 & 11,3 & 23 & 18,5 & \multirow[t]{2}{*}{$p=0,006$} & \multirow{2}{*}{$\begin{array}{c}4.352 \\
(1.569-12.068)\end{array}$} \\
\hline $\begin{array}{l}\text { Berisiko } \\
\text { ( } \geq 35 \text { th) }\end{array}$ & 13 & 10,5 & 88 & 71 & 101 & 81,5 & & \\
\hline \multicolumn{9}{|l|}{ Masa Kerja } \\
\hline $\begin{array}{l}\text { Tidak Berisiko } \\
(<5 \text { th })\end{array}$ & 9 & 7,2 & 10 & 8,1 & 19 & 15,3 & \multirow[t]{3}{*}{$p=0,001$} & \multirow{2}{*}{$\begin{array}{c}6.369 \\
(2.181-18.598)\end{array}$} \\
\hline $\begin{array}{l}\text { Berisiko } \\
(\geq 5 \text { th) }\end{array}$ & 13 & 10,5 & 92 & 74,2 & 105 & 84,7 & & \\
\hline IMT & & & & & & & & \\
\hline $\begin{array}{ll}\text { Tidak } & \text { Berisiko } \\
\text { (normal) } & \end{array}$ & 12 & 9,7 & 30 & 24,2 & 42 & 33,9 & \multirow[t]{2}{*}{$p=0,044$} & \multirow{2}{*}{$\begin{array}{c}2.880 \\
(1.124-7.381)\end{array}$} \\
\hline $\begin{array}{l}\text { Berisiko (gemuk/ } \\
\text { kurus) }\end{array}$ & 10 & 8 & 72 & 58,1 & 82 & 66,1 & & \\
\hline
\end{tabular}

Tabel 2 menunjukkan bahwa terdapat hubungan sikap kerja dengan keluhan MSDs $(p=0,000)$; terdapat hubungan beban kerja dengan keluhan MSDs $(p=0,026)$; terdapat hubungan umur dengan keluhan MSDs $(p=0,006)$; terdapat hubungan masa kerja dengan keluhan MSDs $(p=0,001)$ dan terdapat hubungan IMT dengan keluhan MSDs $(p=0,044)$.

\section{Analisis Multivariat}

Analisis multivariate dilakukan untuk mengetahui faktor mana yang paling berhubungan dengan keluhan musculoskeletal disorders. Hasil analisis dapat dilihat pada tabel berikut: 
Tabel 3 Faktor yang Paling Berhubungan dengan MSDs pada Pekerja Pengangkut Barang Di Pasar Panorama Kota Bengkulu

\begin{tabular}{lcc}
\hline \multicolumn{1}{c}{ Faktor-Faktor } & Sig. & OR \\
& & $\mathbf{9 5 \%}$ \\
\hline Umur & $p=0,157$ & 3,202 \\
& & $(0,639-16,053)$ \\
Masa kerja & $p=0,069$ & 4,728 \\
IMT & $p=0,053$ & $(0,887-25,210)$ \\
Sikap kerja & & 5,352 \\
Beban kerja & $p=0,000$ & $(0,979-29,246)$ \\
& & 87,871 \\
& & $(14,772-522,684)$ \\
& & 4,0855 \\
\end{tabular}

Posisi kerja dengan sikap yang salah dapat meningkatkan energi yang dibutuhkan, sehingga sikap kerja harus sesuai dengan posisi kerja. Posisi kerja yang kurang benar dapat menyebabkan perpindahan dari otot ke jaringan rangka tidak efisien sehingga mudah mengalami kelelahan dalam bekerja. Posisi kerja tersebut merupakan aktivitas dari pengulangan atau waktu lama dalam posisi menggapai, berputar, memiringkan badan, berlutut, memegang dalam posisi statis dan menjepit dengan tangan. Dalam melakukan aktivitas tersebut, dilibatkan beberapa anggota tubuh seperti bahu, punggung dan lutut karena daerah tersebut yang rentan mengalami cedera (4).

Sikap kerja pada penelitian ini ialah postur tubuh pekerja pada saat bekerja. Sikap kerja dikategorikan menjadi dua kelompok, yaitu sikap kerja ergonomis dan tidak ergonomis. Sikap kerja ergonomis memiliki skor REBA berada pada level aksi 0, 1 dan 2 sedangkan sikap kerja tidak ergonomis memiliki skor REBA berada pada level aksi 3 dan 4.

Sikap kerja tidak ergonomis dalam jangka waktu lama dapat menyebabkan keluhan musculoskeletal disorders. Pekerja yang mengalami keluhan musculoskeletal disorders dihitung menggunakan lembar kuesioner nordic body map (NBM). Bagian tubuh yang paling banyak di keluhkan oleh pekerja pengangkut barang di Pasar Panorama Kota Bengkulu yaitu bagian punggung, pinggang, bahu, lengan dan leher. Hal ini dikarenakan sikap kerja saat melakukan pengangkutan barang tidak ergonomis misalnya pergerakan tangan terangkat membentuk sudut $90^{\circ}$, punggung terlalu membungkuk membentuk sudut $60^{\circ}$, kepala terangkat membentuk sudut $>20^{\circ}$ seperti posisi leher yang menekuk sekitar $20^{\circ}$, posisi punggung dan pinggang membungkuk $80^{\circ}$, posisi bertumpu pada kedua kaki namun lutut sedikit menekuk, serta posisi lengan yang menjauhi tubuh $45^{0}$ dan siku menekuk sekitar 200-450. Namun ada juga pekerja yang melakukan pekerjaannya dengan sikap kerja yang ergonomis seperti bertumpu pada kedua kaki serta posisi punggung dan pinggang lurus.

Beban kerja merupakan salah satu faktor yang mempengaruhi terjadinya gangguan otot rangka. Pembebanan fisik pada pekerjaan dapat mempengaruhi terjadinya kesakitan pada muskuloskeletal. Pembebanan fisik yang dibenarkan adalah pembebanan yang tidak melebihi $30-40 \%$ dari kemampuan kerja maksimum tenaga kerja dalam 8 jam sehari dengan memperhatikan peraturan jam kerja yang berlaku. Semakin berat beban maka semakin singkat waktu pekerjaan (6).

Beban yang terlalu berat dapat menimbulkan cedera tulang punggung, jaringan otot dan persendian akibat gerakan yang berlebihan. Suma'mur (2014) menguraikan bahwa cara mengangkut dan mengangkat yang baik harus memenuhi dua prinsip kinetis yaitu Beban diusahakan 


\section{Ullya Rahmawati. \\ Faktor-Faktor yang Berhubungan dengan Keluhan Musculoskeletal Disorders Pekerja Pengangkut Barang di Pasar Panorama Kota Bengkulu}

menekan pada otot tungkai yang keluar dan sebanyak mungkin otot tulang belakang yang lebih lemah dibebaskan dari pembebanan dan Momentum gerak badan dimanfaatkan untuk mengawali gerakan. Penerapan dalam sikap kerja mengangkut beban yang baik yaitu Pegangan harus tepat, Lengan harus berada sedekatnya pada badan dan dalam posisi lurus, Punggung harus diluruskan, Dagu ditarik segera setelah kepala bisa di tegakkan lagi seperti pada permulaan gerakan, Posisi kaki di buat sedemikian rupa sehingga mampu untuk mengimbangi momentum yang terjadi dalam posisi mengangkat dan Beban diusahakan berada sedekat mungkin terhadap garis vertical yang melalui pusat grafitas tubuh.

Berdasarkan hasil observasi, berat beban yang diangkat oleh pekerja pengangkut barang di pasar panorama kota bengkulu berbeda-beda dikarenakan beragam jenis barang yang diangkat, seperti keramik besar (40-50 kg), beras (10-20), semen $(40-50 \mathrm{~kg})$, bahan baku (10-15 kg) mainan (5-10 kg) dan masih banyak lagi. Barang- barang tersebut diangkut secara manual. Sebagian besar berat beban yang diangkat oleh pekerja tidak sesuai dengan kapasitas para pekerja, apabila otot terus menerus dibebankan berat beban yang statis dan melebihi kapasitas maka dapat memicu timbulnya keluhan MSDs.

Keluhan MSDs pertama kali di rasakan pada usia 35 tahun. Seiring bertambahnya usia tingkat keluhan akan terus meningkat. Hal ini terjadi karena pada usia setangah baya kekuatan dan ketahan otot mulai menurun sehingga risiko terjadinya keluhan otot meningkat (7).

Sejalan dengan meningkatnya usia maka akan terjadi degenerasi tulang berupa kerusakan jaringan, penggantian jaringan menjadi jaringan parut dan pengurangan cairan sehingga hal tersebut menyebabkan stabilitas tulang dan otot berkurang.

Pertambahan umur pada masingmasing orang menyebabkan adanya penurunan kemampuan kerja pada jaringan tubuh (otot, tendon, sendi dan ligament). Penurunan elastisitas tendon dan otot meningkatkan sel mati sehingga terjadi adanya penurunan fungsi sehingga tubuh rentan terhadap keluhan muskuloskeletal.

MSDs adalah salah satu penyakit kronis yang membutuhkan waktu lama untuk berkembang. Masa kerja merupakan faktor risiko yang sangat mempengaruhi meningkatnya risiko MSDs, terutama untuk pekerja yang menggunakan kekuatan tinggi. Menurut Ohlsson (1989) semakin lama masa kerja seseorang menyebabkan terjadinya kejenuhan pada daya tahan otot dan tulang secara fisik maupun secara psikis. Hal ini karena tingkat endurance otot yang sering digunakan untuk bekerja akan menurun seiring lamanya seorang bekerja (3).

Masa kerja adalah panjangnya waktu terhitung mulai pertama kali pekerja masuk kerja hingga saat penelitian berlangsung. Masa kerja memiliki hubungan yang kuat dengan keluhan otot dan meningkatkan risiko MSDs terutama untuk pekerjaan yang menggunakan kekuatan kerja yang tinggi.

Seseorang dengan masa kerja lebih dari 5 tahun mempunyai resiko lebih tinggi terpapar NBP dibandingkan dengan seseorang yang masa kerjanya kurang dari 5 tahun. Hal ini dikarenakan pembebanan tulang belakang dalam waktu lama mengakibatkan rongga diskus menyempit secara permanen dan juga mengakibatkan degenerasi tulang belakang. Keluhan MSDs terbanyak pada seseorang dengan masa kerja lebih 5 tahun. Hal ini disebabkan karena pada masa kerja tersebut telah terjadi akumulasi cidera-cidera ringan (5)(1).

Berat badan, tinggi badan dan massa tubuh merupakan factor yang dapat menyebabkan terjadinya keluhan sistem muskulokeletal. Keterikatan IMT dengan MSDs yaitu apabila IMT seseorang tidak normal maka akan bertambah besar risiko orang tersebut untuk mengalami MSDs. Hal ini disebabkan karena seseorang tersebut akan berusaha menopang berat badan dengan cara mengontraksikan otot punggung. Jika ini dilakukan terus menerus dapat menyebabkan adanya penekanan pada bantalan syaraf tulang belakang (7).

Menurut Departemen Kesehatan RI (2003), kategori ambang batas IMT untuk 
orang dewasa Indonesia adalah sebagai berikut :

a. Kurus sekali, jika IMT $<17,0$

b. Kurus, jika IMT 17,0 - 18,4

c. Normal, jika IMT $18,5-25,0$

d. Gemuk, jika IMT 25,1 - 27,0

e. Gemuk sekali, jika IMT $>27,0$

Semakin tidak normal indeks massa tubuh (IMT) seseorang maka akan semakin besar risiko mengalami keluhan MSDs. Hal ini disebabkan karena seseorang dengan IMT yang tidak normal akan berusaha menopang berat badan dengan cara mengontraksikan otot punggung, jika hal ini dilakukan terus menerus dapat menyebabkan adanya penekanan pada bantalan syaraf tulang belakang. Walaupun pengaruhnya kecil Indeks Massa Tubuh (IMT) merupakan faktor yang dapat menyebabkan terjadinya keluhan MSDs (2).

Orang yang memiliki Indeks Massa Tubuh yang tidak normal memiliki kecenderungan adanya peningkatan tekanan mekanik akibat gaya gravitasi pada sistem muskuloskeletal mereka, yang dapat berakibat pada kelelahan sampai terjadinya cedera berupa gangguan muskuloskeletal. Peningkatan tekanan mekanik ini biasanya terjadi pada bagian tubuh atau sendi sendi yang menopang bagian tubuh manusia seperti ekstremitas bawah dan punggung. Pada Carpal Tunnel Syndrome (CTS) peningkatan gangguan muskulosketal di ekstremitas atas dihubungkan dengan adanya peningkatan jaringan adiposa pada bagian carpal tunnel yang menyebabkan penekanan pada saraf median. Selain faktor peningkatan tekanan mekanik, ada juga faktor lain yaitu peningkatan faktor metabolik seperti LDL dan kolesterol.

Khususunya pada bagian lutut merupakan salah satu bagian yang paling sering menderita gangguan muskuloskeletal. Selain karena bagian ini yang merupakan bagian yang paling berat bekerja menahan gaya gravitasi dari berat tubuh manusia, ada beberapa sumber yang menyebutkan adanya keterlibatan Osteoarthritis (OA) dan Rheumatoid Arthritis (RA) sebagai penyebab gangguan musculoskeletal pada ekstremitas bawah. Pada orang dengan IMT tidak normal memiliki efek negatif yang signifikan terhadap gejala gangguan muskuloskeletal pada ekstremitas bawah. terutama hubungannya dalam bidang biomekanika. Ekstremitas Atas, Leher dan Bahu Pada beberapa penelitian menunjukkan hubungan antara Indeks Massa Tubuh dengan terjadinya Osteoarthritis (OA) pada persendian yang tidak memikul beban tubuh seperti pada tangan, termasuk hubungan antara Indeks Massa Tubuh yang tinggi dengan adanya penyakit rheumatoid lainnya seperti fibromyalgia. Diduga bahwa banyak orang menggunakan ekstremitas atasnya sebagai anggota gerak tubuh yang menopang berat tubuh saat mereka beranjak bangun dari posisi duduk yang berkontribusi pada adanya gangguan muskuloskeletal. Secara keseluruhan hasil dari gejala gejala ekstremitas atas, leher dan bahu mengindikasikan bahwa sangat mungkin faktor metabolik merupakan bagian dari mekanisme dasar pada hubungannya dengan Indeks Massa Tubuh.

\section{KESIMPULAN DAN SARAN}

Penelitian ini dapat disimpulkan bahwa terdapat hubungan sikap kerja, beban kerja, umur, masa kerja, indeks massa tubuh dengan keluhan musculoskeletal disorders pada pekerja pengangkut barang di Pasar Panorama Kota Bengkulu dan Faktor yang paling berhubungan dengan keluhan musculoskeletal disorders adalah sikap kerja dengan $p=0,000$ dan OR 87,871. Sebaiknya pekerja dapat mengubah sikap kerja yang tidak ergonomis menjadi ergonomis dan menghindari sikap kerja yang memiliki tingkat resiko pekerjaan yang tinggi.

\section{KEPUSTAKAAN}

1. Amalia 0. Aktifitas Analisis Faktor Risiko Muskuloskeletal Disorders (MSDs) pada Buruh Informal Pasar Grosir Blok F Tanah Abang Jakarta Pusat [Skripsi]. Jakarta: UIN Syarif Hidayatullah; 2010.

2. Depkes RI. (2003). Profil Kesehatan Indonesia. Jakarta: Depkes RI; 2003.

3. Ohlsson K, Attewel RG, Skerfving S. Self-reported Symptoms in The Neck and Upper Limbs of Female Assembly Workers. Scand Journal Work 
Environment Health. 1989. e-journal 15 : pp.75-80.

4. Oktaria S. Posisi Duduk yang Sehat dan Benar Saat Bekerja [Internet]. 2015. Available from: http://www.klikdokter.com.

5. Pratiwi HM. Beberapa Faktor yang Berpengaruh terhadap Keluhan Nyeri Punggung Bawah pada Penjual Jamu Gendong. Semarang. Jurnal Promosi Kesehatan Indonesia. 2009 : 4 (1): 6167.

6. Suma'mur. Higiene Perusahaan dan Kesehatan Kerja. Jakarta: Sagung Seto; 2004.

7. Tarwaka. Ergonomi Industri DasarDasar Pengetahuan Ergonomi Dan Aplikasi Ditempat Kerja. Surakarta: Harapan Press; 2015 
